\title{
THE IMPLEMENTATION OF A POLICY OF FOREST AND LAND FIRE PREVENTION AND MITIGATION IN CENTRAL KALIMANTAN: STUDY OF CENTRAL KALIMANTAN GOVERNOR REGULATION \#49 OF YEAR 2015 ON THE REVOCATION OF GOVERNOR REGULATION \#15 OF YEAR 2010 ON LAND AND YARD OPENING GUIDELINES FOR THE COMMUNITY OF CENTRAL KALIMANTAN
}

\author{
Retamy Cenny*, Rochmah Siti, Hanafi Imam \\ Master's Degree Program in Public Administration, Faculty of Administrative Science, \\ University of Brawijaya, Indonesia \\ *E-mail: cenny.retamy94@gmail.com
}

\begin{abstract}
The implementation of a policy of forest and land fire prevention and mitigation in Central Kalimantan is based on the decree of Central Kalimantan Governor Number 49 of 2015 on the revocation of Governor Regulation Number 15 of 2010 on land and yard opening guidelines for the people of Central Kalimantan. Central Kalimantan is the third largest province in Indonesia and forest fires have become a routine that can not be stopped in which it happens continuously in every year. Considering this, the researcher wanted to describe and analyze the implementation of forest and land fire prevention and mitigation policy in Central Kalimantan. This research is a descriptive research that is implemented with the qualitative approach and data collection techniques by observation, interview, and documentation. The results of this policy implementation on prevention and mitigation of forest and land fire in Central Kalimantan by using Grindle theory consists of policy content, Central Kalimantan Governor Regulation Number 49 of 2015 on the revocation of Governor Regulation Number 15 of 2010 on guidelines of land and yard clearing for the people of Central Kalimantan which has not been well implemented and the strategic policy context that is only used by policy actors at the time of extinction. This has an impact on the society in which they actually do not agree with this revocation. In this case, the government should have a strategy that can control forest fires.
\end{abstract}

\section{KEY WORDS}

Policy implementation, prevention, mitigation, forest and land fires.

Forests are a very important and useful natural resource for the life of living beings. Indonesia itself has abundant natural resources. According to Indonesia Forest Watch and Global Forest Wast (2001) Indonesia is endowed with the vast and richest tropical forest of its biodiversity in the world. In Indonesia, the dominant policy which leads to deforestation is a large plantation, mining, transmigration, public facilities, and fire. Degradation is caused by the activities which according to the law in Indonesia are categorized as illegal acts. Forest fires have enormous impacts in many aspects not only on the ecology and environmental damage but also the social, cultural, and economic significance.

Central Kalimantan is Indonesia's third largest province with an area of approximately $153,564,5 \mathrm{~km}^{2}$. Forest fires have become a routine that happens continuously and can not be stopped. For an instance, in 2015 there was a severe forest fire in this province. In 2015, Central Kalimantan Standard Air Pollution Index (ISPU) has reached a dangerous category. After Hadi Prabowo was appointed as the temporary Governor of Central Kalimantan he revoked Governor Regulation Number 15 of 2010 on the amendment of Governor Regulation Number 52 of 2008 concerning Guidelines for Land and Yard Opening for the Community in Central Kalimantan. This happens with the consideration that the land and yard opening in Central Kalimantan is carried out by burning the land almost in every year during the dry season in which this has contributed to the occurrence of smog that delivers a negative impact on the wider community. Governor Regulation Number 49 of 2015 as a replacement of Revocation of Governor Regulation Number 15 of 2010 on the amendment of Governor 
Regulation Number 52 of 2008 on Guidelines for Land and Yard Opening for the Community in Central Kalimantan.

The existence of Governor Regulation Number 49 of 2015 on the revocation of Governor Regulation Number 52 of 2008 on Guidelines for Land and Yard Opening for the Community in Central Kalimantan is intended to prevent the forest fire and land fire. However, in 2016, forest fires still occur so that Central Kalimantan Provincial Government established an emergency alert status for forest and land fires at that time. The prohibition of land burning by the government policy has received a serious response from the community, especially farmers. They thought that the government does not consider the fate of the people who only rely on farming.

In this case, the government should pay more attention to the central or regional level together with high commitment through the establishment of several policies in the form of regulations. According to Suharno (2013 p.5), public policy is a response of a political system through the government's power towards the problems of the society. Public policy is the government's decision to solve public problems. Nevertheless, the decision may have implications for action or non-action movement.

The policy must be well-implemented in order to achieve a predetermined goal. Meter and Horn (1975) (in Nawawi 2009 p. 131) said that policy implementation is an action undertaken either by individuals or officials or governments or private entities in which it is directed to achieve the outlined objectives in policy decisions. Some approaches in policy implementation are related to the implementation, resources, environment, and problems in the community. Human resources as implementors have an important role in controlling the implementation of public policy. One of the approaches in this implementation is the policy implementation model that is based on Grindle 1980 (in Nawawi p.141) that the success of public policy implementation is influenced by two variables: the content of the policy as to what the program executes, as the resources involved, as the extent of the desired change and, secondly, the context of implementation of how much power and strategy that the implementor have as well as the level of compliance and response of the implementers.

\section{METHODS OF RESEARCH}

This research is a descriptive research with a qualitative approach. Furthermore, the focus of this research are 1) the implementation of policy of prevention and mitigation of forest and land fire in Central Kalimantan in accordance with the regulation of Palangka Raya Governor Number 49 of 2015 about the revocation of governor regulation Number 15 of 2010 of the guidance of land and yard opening for the people of Central Kalimantan by using the model developed by marille S. Grindle which contains: the target group interest, benefit type, degree of desired change, decision-making location, program implementation, and the resources involved. From the context of policy implementation, there are actors strength, interests and strategies, agency characteristics, compliance level, as well as implementation responsiveness. 2) the impact of the policy itself.

The research was conducted in Central Kalimantan, and the site of the research was the Central Kalimantan Disaster Management and Fire Agency. The data used in this study were primary and secondary data with the data sources of informants, places, events, and documents. The data were collected by using interviews, observation, and documents with the research instrument of self-researcher, interview guide, and field notes. The techniques of the data analysis from Miles Huberman and Saldana were also used, which are data condensation, data presentation, conclusion withdrawal and verification.

\section{RESULTS AND DISCUSSION}

The implementation of a policy of prevention and mitigation of forest and land fires in Central Kalimantan Number 49 Year 2015 concerning the revocation of Regulation Central Kalimantan Governor Number 15 of 2010 about the guidelines for land and yard opening for 
the people of Central Kalimantan by using the model of Grindle (in Nawawi 2009 p. 142) is consisted of policy content and context as follows.

1. The contents of the policy. The interests of the target group are in correlation with the interests that affected the policy implementation. In the Governor Regulation Number 49 of 2015, the revocation of Governor Regulation Number 15 of 2010 on land and yard opening guidelines for the people of Central Kalimantan is one of the regulations that permits the clearing of land by burning. In this case, the government considers that the clearing of land and yard by burning in Central Kalimantan in almost every year during the dry season has contributed to the occurrence of smoke haze which has a negative impact on a wider community. Large forest and land fires also create a heavy smog in Central Kalimantan which in this case the interest of the target community is the community.

And then, there is a type of benefit. This means that a policy should be beneficial to the target group. A useful policy will be easier to be implemented than a less useful policy. According to Suharno (2014 p.22), public policy as a response of a political system through the government's power over the problems of the society. Public policy is basically a government decision to solve public problems. With this Governor Regulation, the policy of prevention and mitigation of forest and land fires in Central Kalimantan in the Governor Regulation Number 49 of 2015 on the revocation of Governor Regulation Number 15 of 2010 concerning the clearing of land and yard for the people of Central Kalimantan has provided benefits for the people of Central Kalimantan. It is also not permissible for people and investors to burn the land and forest. Since the enactment of this regulation, Central Kalimantan has been free from smoke in 2016.

After that, it is followed by the degree of change. The degree of change is closely related to the expected benefits of the policy. In the policy of prevention and mitigation of forest and land fires in Central Kalimantan in the Governor Regulation Number 49 of 2015 on the revocation of Governor Regulation Number 15 of 2010 concerning the clearing of land and yard for the people of Central Kalimantan, the desired change is the absence of smoke in the dry season.

Another point is about the decision making location which means that the greater the decision-making position in the policy, the more difficult the implementation. The location of decision making in this Governor Regulation in here is already correct, the Disaster Management and Fire Agency of Central Kalimantan Province (Badan Penanggulangan Bencana dan Pemadam Kebakaran or BPBPK) is directly involved as the implementor, BPBPK is part of the regional apparatus in the field of disaster management under and responsible to the Governor. BPBPK has the task to assist the Governor in organizing, dealing, preventing, preparing, tackling, anticipating, controlling, and evaluating the implementation of disaster management and firefighting.

Besides that, it is important to know the policy implementation. In implementing the policy, there should be supported by a competent and capable policy implemented so that a policy can be implemented properly. The results of interviews in the prevention and handling of forest and land fires has involved various related parties such as The Board of Transportation, Communications, and Information of Central Kalimantan Province, the Disaster Management Agency of Central Kalimantan Province, the Natural Resources Conservation Agency of Central Kalimantan Province, the Plantation Office of Central Kalimantan Province, Climatology, Meteorology, and Geophysical Agency of Palangka Raya, Health Office of Central Kalimantan Province, and Korem 102 Panju Panjung.

Lastly is about the resources involved. Implementing a policy should also be supported by supportive resources. Resources are one of the keys to success in implementing policy implementation. According to Van Meter and Van Horn (in Agustino 2016 p.133), one thing that influences the performance of public policy implementation is the resource. The success of the policy implementation depends on the ability to utilize the available resources. Humans are the most important resource in determining a successful implementation process. In the prevention and mitigation of forest and land fires in Central Kalimantan, human resources are sufficient as stated by the Head of Disaster Management and Fire Agency of Central Kalimantan Province involving Indonesian Military (TNI), National Police (POLRI), Regional 
Government, and the community itself. Furthermore, in the data from BPBPK, it is noted that there are 2,471 people who participated in the management of forest and land fires that are in accordance with its duties and functions.

2. The context of the policy. Strengths, interests, and implementation strategies in a policy need to be taken into account as well as the strengths, interests, and strategies used by the actors in order to smooth the course of the policy implementation. The strength of the Disaster Management and Fire Agency of Central Kalimantan has been legally established in accordance with the Central Kalimantan Provincial Regulation Number 10 of 2010 concerning Organization and Working Procedures of Disaster Management Agency of Central Kalimantan Province. To support the mechanism, there is a regulation Number 24 of 2017 on Disaster Management as the institutional basis of the agency. The establishment of the Disaster Management and Fire Agency of Central Kalimantan Province (Badan Penanggulangan Bencana dan Pemadam Kebakaran or BPBPK) has been carried out in 12 districts or cities. Also, there is a budget allocation from the regional budget as well as a support from the national budget. The interest that influences this policy is the interest of the community which is the people who live in the community while having interests in the economic field, they suffered economic losses. The strategy of the Disaster Management and Fire Agency of Central Kalimantan Province is still weak because it is only conducted in the event of an extinguishment. In this case, they should have a strategy of prevention, extinguishment, and after the fire.

Secondly is the characteristic of implementation agency. The Disaster Management and Fire Agency of Central Kalimantan Province perform its function to coordinate the disaster management in a planned, integrated, and comprehensive action. As stated by the Head of Control Operation of Disaster Management and Fire Agency of Central Kalimantan Province that BPBPK is only limited to coordination, for example, a coordination meeting that talks about the prevention and mitigation of forest and land fires with related agencies.

Next, we come to the level of compliance and responsiveness of the policy actors. In the process, a compliance and responsiveness of the implementer is an important part that will affect the implementation of a policy. BPBKP in here is the implementor involved in the implementation of forest fire prevention and mitigation in Central Kalimantan. The BPBPK of Central Kalimantan has prepared the control of forest and land fires such as conducting coordination meetings prior to the dry season and taking a preventive action by drafting the Forest and Land Fire Action Plan. Based on the interview with the Head of Prevention and Mitigation of Disaster Management and Fire Agency of Central Kalimantan Province, there are still many obstacles encountered in the implementation of forest and land fire control which is mainly in funds and preparation (very minimal).

The impacts of prevention and mitigation policies on land and forest fires in Central Kalimantan is in accordance with Central Kalimantan Governor Regulation Number 49 of 1955 on the revocation of Governor Regulation Number 15 of 2010 on land and yard opening guidelines for the people of Central Kalimantan are:

1. The impact on society. The revocation of this Governor Regulation has impacted the community. It also can be seen that the withdrawal of the Governor Regulation Number 49 of 2015 on the revocation of Governor Regulation Number 15 of 2010 on land and yard clearing guidelines for the people of Central Kalimantan gives positive and negative impacts to the community. The positive impact is the absence of smog in 2016 that is in contrast with what had happened in 2015 (before the Governor's Revocation), public health in this case also increased in 2016 during the dry season. Meanwhile, the negative impact of this regulation is the people, especially people who live in the regional area can not do its farm while some of them only have a living from the farm.

2. Society change and acceptance. Since the Governor's Regulation, the society has become more vigilant and as for the people in the village, they feel threatened by the Governor's Regulation. They disagree with the existence of this rule. As mentioned by some residents from Rantau Pulut, Seruyan Tengah that the reason why they disagree with this rule is because they can not farm while they only rely on farming. "We can not eat unless we farm» so that they ask for a solution from the government. 


\section{CONCLUSION}

Based on the policy implementation of forest and land fire prevention and mitigation in Central Kalimantan, it can be concluded that the interest of the community as a target group is very influential. This policy has made the people of Central Kalimantan free from smoke. In Central Borneo, since the enactment of this Governor Regulation, the forest and land fires has decreased. BPBPK as an implementor of this policy has been working with relevant agencies and other human resources in which they have prepared other resources in the form of facilities and infrastructure. With the support of funds from the national and regional budget and the Governor Regulation implementation, public interest in the economic field is affected, the people seem to experience economic losses. Furthermore, the government's interest in here is noted to create a smoke-free Central Kalimantan with the strategy that is only at the time of extinguishment. BPBPK only acts as a coordinator of policy guidelines and disaster management deployment which covers disaster prevention. In regard to the Governor Regulation Number 49 of 2015, some BPBPK employees do not approve the revocation of this Governor Regulation. The impact of this prevention and mitigation for the community is both positive and negative. The public does not approve the revocation of this regulation because it prohibits them from burning land. They consider that if the land is not burned, the rice will not be able to grow.

\section{REFERENCES}

1. Adinugroho, W.C., I.N. Suryadiputra, B.H. Saharjo, L. Siboro. 2005. Panduan Pengendalian Kebakaran Hutan dan Lahan Gambut. Bogor : Proyek Climate Change, Forest and Peatland in Indonesia, Weatland International Indonesia Programme and Wildfire Habitat Canada.

2. Glover, D and T. Jessup. 2002. Mahalnya Harga Sebuah Bencana; Kerugian Lingkungan Akibat Kebakaran dan Asap di Indonesia. Penerbit ITB. Bandung.

3. Meleong, Lexy J. 2014. Metodelogi penelitian kualitatif. Bandung: PT Remaja Rosdakaraya.

4. Miles, Matthew B, A. Michael Huberman dan Johny Saldana. 2014. Qualitative Data Analysis, A Methods Sourcebook Edisi ketiga. Sage Publications: Inc.

5. Nawawi, Ismail. 2009. Public Policy, Analisis, Stretegi Advokasi Teori dan Praktek. Penerbeitan Pertama, Surabaya: CV. Putra Media Nusantara.

6. Subarsono. 2005. Analisis Kebijakan Publik, konsep, Teori dan Aplikasi. Yogyakarta: Puataka Belajar. 